\title{
Introduction to Climate Change Law
}

In the preceding decades, the attributes of climate change-including long time horizons, complex science, numerous and widespread contributors, and disparate geographic impacts - repeatedly intersected with political and legal processes to frustrate the development of effective mitigation laws and policies. Climate change thus lives up to its billing as a "super wicked" public policy problem defying ready solution. ${ }^{1}$ Current commitments by countries to reduce atmospheric greenhouse gases (GHGs) fall far short of what is necessary to limit climate change and its impacts to tolerable levels. Even if every party honors its non-binding commitments under the Paris Agreement, models project that warming will, within this century, significantly exceed $2{ }^{\circ} \mathrm{C}$, the level of warming generally recognized as the maximum tolerable. ${ }^{2}$ To put this in perspective, the present-day manifestations of "just" a little over $1{ }^{\circ} \mathrm{C}$ warming - wildfires, flooding, storms - are proving to be deadly, costly, and dislocating; as discussed in the next chapter, scientists project even more serious, irreversible impacts with warming of even $1.5^{\circ} \mathrm{C}$. Yet knowledgeable observers caution that "barring rapid global political, social, and technological transformations ... we will be fortunate to limit temperature rise to $2.6^{\circ} \mathrm{C}$, just as likely to reach $3.9^{\circ} \mathrm{C}$, and the possibility of reaching $4.0^{\circ} \mathrm{C}$ or higher cannot be ignored." ${ }^{3}$

To avoid the devastating climate change impacts hovering at the edges of climate models, the present moment must be an inflection point marking a rapid transition from an extended period of study, debate, planning, and preliminary emission reduction efforts to a period of rapid, effective implementation of climate change mitigation measures. Myriad developments, ranging from the adoption of aggressive GHG emissions targets by some countries and some states within the United States (US) to the declining market value of

For further insight into why it is so difficult to develop climate change mitigation law and policy see Richard J. Lazarus, Super Wicked Problems and Climate Change: Restraining the Present to Liberate the Future, 94 CORNELL L. Rev. 1153, 1159-1187 (2009).

2 United Nations Environment Programme, Emissions Gap Report 2019 Figure ES.4 (2019), https://www.unep.org/emissions-gap-report-2020. 2021). 
major fossil fuel companies, signal the possibility that climate change policy is turning this corner. But time is short. Humans emit about $40 \mathrm{Gt}$ of carbon into the atmosphere per year, which puts us on track, by many estimates, to use up our carbon budget (the total amount of carbon that can be put into the atmosphere to retain a decent chance of keeping warming below $1.5^{\circ} \mathrm{C}$ or $2^{\circ} \mathrm{C}$ ) by about the mid-2030s; in 2019, scientists warned that when the release of naturally sequestered carbon (from permafrost emissions or forest dieback, for example) is factored in, the world may have already used up the carbon budget. $^{4}$

And the task to achieve adequate near-term carbon reductions is herculean. Legal Pathways to Deep Decarbonization, a comprehensive guide for how to achieve meaningful mitigation in the US, identifies over a thousand laws and policies relevant to decarbonization, providing some perspective on the scope and nature of what decarbonization will require. ${ }^{5}$ Mitigation interventions will need to change not just how we generate energy (swapping out fossil fuel combustion for renewable sources of energy), but how we use it (swapping out cars with internal combustion engines for electric vehicles and natural gas appliances for electric ones). Adopting and implementing these interventions will, in turn, require broad participation, sustained political will, informed policy judgment, and sophisticated legal acumen. It is all hands on deck-indeed, the editors of Legal Pathways to Deep Decarbonization are coordinating an effort to engage lawyers pro bono across numerous fields of legal practice to contribute to decarbonization efforts. ${ }^{6}$

This underscores the importance for citizens, policymakers, and lawyers to be literate in the core aspects of climate change law and policy. Yet individuals interested to understand the contours of climate change law and policy face a challenge. The law and policy of climate change mitigation is overwhelming in its breadth, the diversity of its origins, and the complexity of its content. It arises and is enforced at all levels of government, from the adoption of energy-efficient building codes by local governments to federal laws governing the emissions of pollutants from industrial sectors. It is interpreted and applied by a diverse array of institutions, including dozens of federal and state agencies and federal and state courts in myriad jurisdictions. Relevant authorities include statutes, the regulations interpreting them, agency guidance and thousands of court decisions. And the underlying legal subjects with which climate change law and policy intersects include not just environmental

\footnotetext{
$4 \quad I d$.

5 Legal Pathways to Deep Decarbonization in the United States (Gerrard \& Dernbach eds.) (2018).

6 Model Laws for Deep Decarbonization in the United States, https://pdd.org/ pathways/ (last visited 4/21).
} 
and energy law; nearly all legal subjects intersect in some significant manner with climate change. Indeed, at the Elisabeth Haub School of Law at Pace University, the once or current home institution of the authors of this book, faculty have discussed whether and how to include coverage of climate change in every course taught at the school.

The breadth and diversity of climate change law and the fact that it touches nearly every legal subject and practice area invite the question of whether it is productively considered a distinct area of law at all. ${ }^{7}$ Yet, regardless of whether climate change law is ultimately understood to formally constitute a unique subject of legal inquiry, it is imperative - in the sense that our collective future depends upon it-for law to develop and support effective climate change mitigation policy.

Helping individuals seeking to engage with climate change law and policy to develop climate change law literacy is the raison d'étre of this book. It provides background information necessary for readers to knowledgably navigate climate change law and policy. The chapters scaffold understanding of key issues by introducing and defining key terms, authorities, and actors; identifying important policy considerations; explaining the contours of significant legal disputes and questions; and highlighting the most salient aspects of emerging mitigation policy and associated legal issues. Readers should develop a sense of the broad landscape of climate change law and policy as well as familiarity with important terms, institutions, actors, and issues that will equip them to independently take deeper dives into specific areas of interest. The goal, in short, is to make readers literate in climate change mitigation law and policy, thereby empowering them to engage further with climate change mitigation efforts.

The first chapter, "International Climate Change Treaty Regime," explains the key provisions of the Paris Agreement, emphasizing how and why domestic

7 Compare Frank H. Easterbrook, Cyberspace and the Law of the Horse, 1996 U. CHI. Legal F. 207 (1996) (arguing that "the best way to learn the law applicable to specialized endeavors is to study general rules") with Lawrence Lessig, The Law of the Horse: What Cyberlaw Might Teach, 113 HaRv. L. Rev. 501, 503 (1999) (responding that the study of cyberlaw, and perhaps other specialized areas, may provide "lessons for law generally"). See also Douglas A. Kysar, What Climate Change Can Do About Tort Law, 42 EnvtL. L. ReP. News \& ANALysis 10739 (2012) (explaining how climate change may influence the development and understanding of tort law); J.B. Ruhl \& James Salzman, Climate Change Meets the Law of the Horse, 62 Duke L.J. 975, 1019 (2013) (evaluating whether the law of climate change adaptation constitutes a distinct field and observing that "it may very well be that no existing field of law is rendered obsolete by climate change, but that more than a Law of the Horse is needed-that is, a distinct field of climate adaptation theory and practice is nonetheless necessary and appropriate to manage policy goals that no individual field can address."). 
policymaking will be crucial for achieving its objectives. Chapter 2, "Climate Law Primer: Mitigation approaches," then identifies and describes federal policies to reduce GHG emissions in the US, reviewing the basic structure of pollution control approaches and assessing existing and potential future application of these approaches to mitigation, including under the federal Clean Air Act. Chapter 3, "Introduction to Energy Law," focuses on the role of energy law in mitigation, providing an overview of public service and administrative law, and laws governing the development of energy projects, the regulation of energy in the buildings sector, and the transportation sectors. And Chapter 4, "Adaption to Climate Change at the Subnational Level," supplements the preceding analyses by highlighting the role of regional, state, and local law in developing and implementing climate change policy. Together, the first four chapters provide an accessible tour of current climate change policy in the US, with particular attention to identifying emerging issues and forecasting likely developments.

The remaining chapters consider important legal doctrines and ethical principles that inform, define, and shape the development of climate change policy. Chapter 5, "Litigating Government (In)Action on Climate Change," explores catalyst litigation to force governments to require stronger mitigation action through robust enforcement of existing statutes of general application or by invoking extra-statutory sources of government obligation, including common law and constitutional law. Chapter 6, "Human Rights and Climate Change," examines the relationship between human rights and climate change using the framework of international human rights law, including by considering how human rights law has evolved to elaborate states' obligations to mitigate and adapt to climate change, and to address the needs of those most vulnerable to climate-related harms. Chapter 7 focuses on possibilities for using law to prompt mitigation or compensation for climate harms by holding private actors that contribute to climate change accountable and/or persuading them to voluntarily reduce emissions. This includes evaluating lawsuits brought directly against large emitters and fossil fuel producers by those suffering harms from climate change and evaluating how disclosure under federal securities laws can support mitigation by private actors. The book concludes by turning the focus to individuals, observing that ultimately the development and implementation of effective climate change policy will rest on collective acknowledgment of a shared ethical responsibility. Chapter 8, "Why the Individual Ethics of GHG Emissions Matter to Climate Law," looks to prevailing ethical theories of utilitarianism, deontology, and virtue ethics to show that individuals have a moral responsibility to reduce and moderate their lifestyle greenhouse gas emissions. 